\title{
Klasifikasi Keluhan Tamu Mengenai Pelayanan Front Office di The Westin Resort Nusa Dua Bali Berdasarkan Ulasan pada Tripadvisor
}

\author{
Putu Diana Ayu Pratiwi ${ }^{*}$, I Gusti Ayu Putu Wita Indrayani2*, I Made Sucipta Adnyana ${ }^{3}$ \\ 1,2,3 Manajemen Divisi Kamar, Politeknik Pariwisata Bali \\ Jl. Dharmawangsa, Kampial, Nusa Dua. Ph. (0361) 773537 \\ 1*dianapratiwi.da@gmail.com, 2witavenus@gmail.com, , 3adnyanasucipta@gmail.com \\ *Corresponding author
}

\begin{tabular}{l|l|l} 
Received: Oktober, 2021 & Accepted: Oktober, 2021 & Published: Desember, 2021
\end{tabular}

\begin{abstract}
The purpose of this study is to discover the reasons and effects of recurring complaints based on the classification of guest complaints about Front Office services at The Westin Resort Nusa Dua Bali, in order to identify alternative methods to reduce the number of guest complaints. The data was gathered through documentation on TripAdvisor and an interview with the Front Office Manager, and the data analysis technique applied was descriptive qualitative. The analysis's findings revealed the reasons and consequences of guest complaints about Front Office services, which were classified into two categories: servicerelated complaints and attitudinal issues. Furthermore, the front office service procedures have not achieved 100 percent compliance with the SOP during the guest cycle. In the case of attitudinal complaints and service-related complaints, the reason of the complaints was determined as a disparity in SOP. This research was effective in enhancing comprehension of the reasons and effects of guest complaints regarding Front Office services on Online Travel Agents. Based on the research that has been conducted, suggestions should be addressed to hotel management as an alternate option to reduce problems that have occurred by enrolling in training.
\end{abstract}

Keywords: guest complaints, service, front office, standard operating procedure

\begin{abstract}
Abstrak
Penelitian ini bertujuan untuk mengetahui penyebab dan dampak dari keluhan tamu berdasarkan klasifikasi keluhan tamu mengenai pelayanan Front Office di The Westin Resort Nusa Dua Bali, sehingga dapat mengidentifikasi solusi alternatif untuk mengurangi keluhan yang berulang. Data yang digunakan diperoleh melalui studi dokumentasi pada TripAdvisor dan wawancara dengan Front Office Manager dengan teknik analisis data yang digunakan yaitu teknik analisis deskriptif kualitatif. Hasil analisis menunjukkan penyebab dan dampak dari keluhan tamu berdasarkan klasifikasi keluhan tamu mengenai pelayanan Front Office yang terbagi menjadi dua aspek yaitu service-related complaint dan attitudinal complaint. Selain itu, prosedur pelayanan Front Office belum mencapai 100\% kesesuaian dengan SOP pada siklus tamu. Ketidaksesuaian SOP tersebut diidentifikasi sebagai penyebab keluhan pada aspek service-related complaint dan attitudinal complaint. Penelitian ini bermanfaat
\end{abstract}


Klasifikasi Keluhan Tamu Mengenai Pelayanan Front Office di The Westin Resort Nusa Dua Bali Berdasarkan ......

Putu Diana Ayu Pratiwi, I Gusti Ayu Putu Wita Indrayani, I Made Sucipta Adnyana

untuk meningkatkan pemahaman dalam mengidentifikasi penyebab dan dampak dari keluhan tamu mengenai pelayanan Front Office pada Online Travel Agent dengan mengetahui klasifikasi dari keluhan tamu. Berdasarkan penelitian yang telah dilakukan, saran yang bisa diberikan kepada pihak manajemen hotel sebagai solusi alternatif untuk mengurangi masalah-masalah yang terjadi yaitu dengan cara mengikuti pelatihan

Kata kunci: keluhan tamu, pelayanan, kantor depan, standar prosedur operasional

\section{PENDAHULUAN}

Keluhan merupakan ungkapan rasa ketidakpuasan para tamu karena apa yang mereka dapatkan tidak sesuai dengan apa yang diharapkan. Menurut Bell dan Luddington (2014), keluhan adalah umpan balik (feedback) dari pelanggan yang ditujukan kepada perusahaan yang cenderung bersifat negatif. Umpan balik ini dapat dilakukan secara tertulis maupun lisan. Keluhan dapat diklasifikasikan berdasarkan aspek keluhan dan jenis keluhannya. Aspek keluhan menunjukkan kategori dari penyebab keluhan yaitu service related complaint dan attitudinal complaint. Sedangkan jenis keluhan menunjukkan garis besar masalah yang dikeluhkan tamu. Klasifikasi merupakan proses pengelompokkan yang sistematis atas dasar tertentu dari suatu objek. Klasifikasi keluhan tamu adalah proses pengelompokkan yang sistematis dari bentuk ketidakpuasan tamu terhadap perusahaan yang dilakukan secara tertulis maupun lisan.

Keluhan umumnya disampaikan oleh tamu selama tamu menginap atau saat tamu sudah meninggalkan hotel (check-out). Menurut Murphy (2020), 74\% tamu akan memberikan ulasan pada Online Travel Agent saat diminta oleh suatu perusahaan. Menurut Saputra (2021:19), perkembangan teknologi di era digital ini telah membawa dunia pariwisata pada era baru yaitu e-tourism. Jadi segala bentuk penilaian tamu mengenai aktivitas pariwisata termasuk pelayan yang telah didapatkan setelah tamu menginap di hotel biasanya akan tertulis dalam bentuk tulisan pada OTA yang disebut ulasan. Ulasan merupakan salah satu bentuk evaluasi tamu terhadap pengalaman selama tamu menginap. Menurut Mullachery (2014), 93\% wisatawan dunia mengungkapkan bahwa ulasan pada Online Travel Agent sangat berpengaruh terhadap pertimbangan serta keputusan calon tamu untuk melakukan pemesanan kamar.

Menurut Sugiarto dalam Septiani (2017:30), keluhan tamu dapat diklasifikasikan kedalam empat bagian utama yaitu: 1) mechanical complaint, yaitu keluhan yang terjadi karena tidak berfungsinya salah satu peralatan yang diperoleh dari suatu interaksi pelayanan, 2) attitudinal complaint, yaitu keluhan yang terjadi karena sikap negatif dari petugas pelayanan saat melayani tamu, 3) service related complaint, yaitu keluhan yang terjadi karena pelayanan itu sendiri, dan 4) unusual complaint, yaitu keluhan yang terjadi dan disampaikan kepada petugas, namun menurut petugas keluhan tersebut adalah keluhan yang tidak wajar. Secara umum faktor yang menyebabkan tamu mengeluh adalah kesenjangan antara harapan tamu dengan pelayanan yang diberikan sehingga tamu merasa tidak puas. Menurut Gonius (2013:8), ada lima dimensi penyebab keluhan tamu yaitu tanggung jawab (Responsiveness), pertolongan dari petugas (Helpfulness), ketersediaan produk (Product availability), harga dan pembayaran (Price and payment), dan sikap petugas (Attitude).

Tamu yang datang dan menginap di hotel pasti punya tujuan dan maksud tertentu. Menurut Sambodo (2020:21), semua proses kegiatan tamu mengacu pada tahapan atau fase yang disebut siklus kegiatan tamu. Fase pertama sebelum kedatangan tamu disebut dengan pre-arrival. Sebelum tamu menginap, tamu akan melakukan pemesanan terlebih dahulu. Pencatatan segala pemesanan tamu mulai dari kamar sampai permintaan khusus akan dicatat oleh reservasi. Fase kedua adalah kedatangan tamu (Arrival). Pada tahap kedatangan tamu meliputi registrasi dan pengalokasian kamar. Fase berikutnya adalah tamu menginap (In-house Guest). Selama tamu menginap adalah saat paling penting, 
karena saat itulah tamu bisa merasakan seberapa baik kualitas petugas hotel dalam memberikan pelayanan. Pada siklus ini, petugas Front Office berupaya dalam menangani keluhan tamu apabila terjadi hal yang menyebabkan ketidakpuasan terhadap suatu pelayanan. Fase terakhir yang tidak kalah penting adalah fase keberangkatan tamu (departure). Pada tahap keberangkatan dalam siklus tamu, tamu akan datang ke front desk untuk melakukan proses check-out. Setiap tahapan tersebut harus dikelola secara maksimal agar dapat mencapai kualitas pelayanan dan kepuasan tamu.

Salah satu karya paling awal dalam kualitas layanan, diusulkan oleh Parasuraman et al. $(1985,1988)$ mengukur kepuasan pelanggan sebagai kesenjangan antara layanan yang diharapkan dan layanan yang dirasakan. Konsep kualitas layanan telah menjadi subjek yang populer dan cukup penting baik oleh praktisi maupun peneliti selama lebih dari dua decade.

Kepuasan tamu dapat diukur dengan melihat rating pada ulasan tamu di Online Travel Agent. Semakin tinggi rating yang diberikan tamu maka semakin tinggi tingkat kepuasan tamu terhadap kualitas pelayanan dan fasilitas yang didapatkan tamu. Namun, semakin rendah rating yang diberikan tamu maka semakin rendah tingkat kepuasan tamu terhadap kualitas pelayanan dan fasilitas yang didapatkan tamu. Khoo-Lattimore dan Ekiz (2014) mempelajari kualitas hotel bintang lima melalui ulasan online dan mengungkapkan bahwa pujian tamu jatuh ke dalam lima kategori utama, yaitu, kamar, staf, makanan, layanan, dan lokasi. Penelitian juga menunjukkan bahwa para tamu menghargai peningkatan kamar, check-out terlambat, penjemputan limusin, dan layanan antar-jemput gratis ke bandara sebagai fitur layanan yang menghasilkan kesenangan tamu. Ali (2015) dalam sebuah studi di hotel resor Malaysia, menetapkan bahwa persepsi yang lebih baik tentang suasana hotel dan kesopanan staf, produk makanan dan minuman, kinerja dan pengetahuan staf, layanan reservasi, dan nilai finansial lebih mungkin untuk mengembangkan kepuasan pelanggan. Hal ini juga sejalan dengan penelitian yang dilakukan oleh Padma dan Ahn (2020).

Berdasarkan Tabel 1 menunjukan klasifikasi keluhan tamu terrible dan poor. Dalam TripAdvisor, terrible adalah ulasan yang disimbolkan dengan rating bintang satu $\left({ }^{*}\right)$ dengan indikator sangat buruk. Sedangkan poor adalah ulasan yang disimbolkan dengan rating bintang dua $\left({ }^{* *}\right)$ dengan indikator buruk.

Tabel 1: Data Klasifikasi Frekuensi Ulasan Mengenai Keluhan Tamu Terhadap Pelayanan Front Office Periode 2017-2020

[Sumber: TripAdvisor]

\begin{tabular}{lccccc}
\hline Tahun & 2017 & 2018 & 2019 & 2020 & Total (Orang) \\
\hline Terrible $\left(^{*}\right.$ ) & 5 & 6 & 7 & 2 & 20 \\
Poor $\left(^{* *}\right)$ & 1 & 4 & 10 & - & 15 \\
Total (Orang) & 6 & 10 & 17 & 2 & 35 \\
Frekuensi (\%) & $17 \%$ & $28 \%$ & $49 \%$ & $6 \%$ & $100 \%$ \\
\hline
\end{tabular}

Ulasan tamu sangat berkaitan dengan tingkat hunian kamar begitupun sebaliknya. Menurut Bonelli (2016), 70\% tamu akan memberikan ulasan pada OTA setelah tamu menginap, sehingga tingkat hunian kamar sangat berpengaruh pada tingkat ulasan tamu pada OTA. Semakin tinggi tingkat hunian kamar, maka semakin tinggi ulasan tamu pada OTA. Pada tahun 2019 tingkat hunian kamar yaitu 80\%, tingkat hunian tersebut adalah tingkat hunian tertinggi selama lima tahun terakhir karena adanya beberapa International Big Event yang diselenggarakan di Hotel The Westin Resort Nusa Dua Bali. Tabel 1.1 menunjukkan ulasan mengenai keluhan tamu tertinggi terjadi pada tahun 2019 yaitu keluhan tamu berjumlah 17 orang dengan persentase 49\%. Sedangkan pada tahun 2020 tingkat hunian kamar yaitu 20\%, tingkat hunian tersebut adalah tingkat hunian terendah selama tahun 2017-2020. Hal tersebut dikarenakan tingkat hunian kamar mengalami 
penurunan setiap bulannya pada tahun 2020. Hal tersebut disebabkan karena adanya pandemi Covid-19 yang menyerang hampir seluruh bagian negara. Hal tersebut menyebabkan frekuensi wisatawan dunia yang biasanya melakukan aktivitas pariwisatanya ke Bali mengalami penurunan. Sehingga pada tahun 2020, keluhan tamu hanya berjumlah dua orang dengan persentase $6 \%$.

Keluhan merupakan suatu hal yang harus diperhatikan dan tidak bisa diabaikan. Karena dengan mengabaikan keluhan dari tamu, tamu akan merasa tidak dihargai, maka dari itu perusahaan harus bisa mencari solusi untuk menyelesaikan keluhan tamu sebelum tamu meninggalkan hotel. Menurut Kusumastuti dan Yonasari (2018), keluhan yang ditunjukkan tamu biasanya bersumber dari beberapa faktor yaitu, faktor sumber daya manusia, faktor alat dan bahan, dan faktor pelayanan. Survei Blumenthal (2016) menyatakan bahwa 57\% dari penyebab keluhan tamu adalah rasa kecewa terhadap pelayanan petugas hotel.

The Westin Resort Nusa Dua Bali dalam mottonya "Westin for a Better You" menerapkan program Six Pillars of Well-Being. Berdasarkan wawancara secara langsung dengan Front Office Manager, program tersebut adalah salah satu program dari pihak hotel untuk meningkatkan kualitas kenyamanan tamu selama menginap. Sehingga dapat diinterpretasikan bahwa The Westin Resort Nusa Bali menerapkan keluhan yang terjadi dengan frekuensi yang seminimal mungkin. Jadi, sekecil apapun keluhan tamu terhadap produk maupun pelayanan harus ditindaklanjuti sebelum tamu meninggalkan hotel. Keluhan-keluhan yang terjadi harus diperhatikan oleh pihak hotel dan harus segera ditangani. Keluhan yang tidak ditangani dengan baik akan berdampak kurang baik bagi kelangsungan operasional hotel.

Dari pemaparan sebelumnya, menunjukkan bahwa masih banyaknya keluhan tamu mengenai pelayanan Front Office di The Westin Resort Nusa Dua Bali berdasarkan ulasan pada Online Travel Agent yakni TripAdvisor. Berdasarkan wawancara dengan Front Office Manager, The Westin Resort Nusa Bali memiliki SOP sebagai standard yang ditetapkan Departemen Front Office untuk petugas Front Office melaksanakan tugasnya dalam melayani tamu. Faktor penyebab terjadinya keluhan yang berulang kali diduga karena Standard Operational Procedure yang diterapkan petugas Front Office kurang maksimal. Hal tersebut seperti, dalam melayani tamu check-in, petugas Front Office harus mengalokasikan permintaan tamu sesuai dengan reservasi lalu mengkonfirmasikannya kepada tamu secara langsung. Namun pada kenyataannya ada petugas Front Office yang tidak mengalokasikan tamu sesuai dengan reservasi. Hal tersebut terjadi karena tingginya tingkat occupancy yang menyebabkan kamar yang dipesan tamu tidak tersedia saat checkin, sehingga untuk mempercepat proses check-in, petugas Front Office memberikan kamar yang tersedia pada saat itu kepada tamu. Hal tersebut menimbulkan keluhan pada tamu. Keluhan yang terjadi secara berulang yang ditujukan pada pelayanan yang diberikan petugas Front Office perlu dikelola.

Kualitas pelayanan telah mendapatkan fokus pada hotel-hotel mewah di negaranegara berkembang. Misalnya, Mohsin et al. $(2010,2011)$ meneliti kualitas pelayanan di hotel Pakistan. Mereka menyimpulkan bahwa layanan kamar, kebersihan dan kenyamanan serta penanganan keluhan adalah area yang paling penting untuk difokuskan, mengingat pentingnya peringkat tamu. Rhee dan Yang (2015) membandingkan harapan tamu dan pengalaman aktual mereka di hotel mewah. Hal ini mengindikasikan mengenai pentingnya penanganan keluhan tamu di hotel luxury. Berdasarkan uraian pada latar belakang masalah diatas, maka yang menjadi pokok masalahnya adalah "“Bagaimanakah klasifikasi keluhan tamu mengenai pelayanan Front Office di The Westin Resort Nusa Bali berdasarkan ulasan pada TripAdvisor?". Penelitian ini dilakukan untuk mengetahui klasifikasi keluhan tamu mengenai pelayanan Front Office yang ada di The Westin Resort Nusa Bali pada ulasan di TripAdvisor. Setelah mengetahui hal tersebut, diharapkan dapat 
mengidentifikasi penyebab dan dampak dari keluhan tamu serta solusi alternatif atau upaya untuk mengurangi keluhan yang berulang.

\section{METODE PENELITIAN}

Penelitian ini menggunakan metode analisis deskriptif kualitatif. Menurut Mukhtar (2013:10) Metode penelitian deskriptif kualitatif adalah suatu metode yang digunakan untuk menemukan pengetahuan terhadap subjek penelitian pada saat tertentu. Dalam teknik analisis data ini, penulis akan memproses data dari studi dokumentasi dengan mengacu pada teori klasifikasi keluhan tamu yang menurut Sugiarto dalam Septiani (2017:30) klasifikasi keluhan tamu dibagi menjadi empat bagian utama yaitu mechanical complaint, service related complaint, attitudinal complaint, dan unsual complaint. Data tersebut nantinya akan di sort out dengan hanya berfokus pada keluhan tamu mengenai pelayanan Front Office pada aspek service related complaint dan attitudinal complaint saja. Setelah data terkumpul, data akan dicari frekuensinya dari setiap jenis keluhan yang ada, selanjutnya data akan diinterpretasi dengan cara mengidentifikasi dan mendeskripsikan spesifik keluhan dari setiap jenis keluhan yang ada dengan aspek keluhan. Selanjutnya mengidentifikasi penyebab dari terjadinya keluhan tamu berdasarkan wawancara mengenai SOP yang diterapkan petugas Front Office dalam melayani tamu dengan Front Office Manager, setelah itu mengidentifikasi dampak dari keluhan tamu terhadap operasional Front Office. Kemudian mengidentifikasi solusi alternatif untuk mencegah terjadinya keluhan yang berulang.

\section{HASIL DAN PEMBAHASAN}

\subsection{Deskripsi Data}

Studi dokumentasi pada ulasan TripAdvisor dalam memperoleh data ini dilakukan selama satu minggu, mulai dari 24 April hingga 01 Mei 2021. Data yang dikumpulkan dan diproses adalah data selama empat tahun mulai dari 2017-2020, hal ini bertujuan untuk mengetahui frekuensi dari keluhan yang berulang atau keluhan yang paling dominan mengenai pelayanan Front Office. Setelah mengumpulkan data, ditemukan sebanyak 68 keluhan yang ditujukan kepada Front Office. Menurut Sugiarto dalam Septiani (2017:30), keluhan tamu dapat diklasifikasikan kedalam empat aspek keluhan yaitu mechanical complaint, attitudinal complaint, service related complaint, dan unusual complaint. Keluhan tamu disebabkan karena banyak hal, menurut Gonius (2013:8), ada lima dimensi penyebab keluhan tamu yaitu, tanggung jawab, pertolongan dari petugas, ketersediaan produk, harga dan pembayaran, dan sikap petugas.

Berdasarkan data yang telah dikumpulkan dan dikaji ulang, data yang dianalisis hanya berfokus pada 35 tamu yang mengeluh. Hal ini dikarenakan keluhan yang paling signifikan dengan pelayanan Front Office adalah keluhan pada aspek pelayanan dan aspek sikap petugas. Keluhan tamu mengenai pelayanan Front Office di The Westin Resort Nusa Dua Bali diklasifikasikan kedalam dua aspek keluhan tamu yakni, service related complaint atau keluhan mengenai pelayanan dan attitudinal complaint atau keluhan mengenai sikap petugas. Berdasarkan data keluhan tamu pada ulasan di TripAdvisor yang sudah diolah, klasifikasi, dimensi penyebab, serta jenis keluhan tamu mengenai pelayanan Front Office dapat dilihat pada Tabel 2.

Tabel 2: Data Frekuensi Klasifikasi dan Dimensi Penyebab Keluhan Tamu Mengenai Pelayanan Front Office Periode 2017-2020

[Sumber: TripAdvisor]

\begin{tabular}{clcc}
\hline Aspek & Dimensi & Jenis Keluhan & Jumlah \\
Keluhan & Penyebab & & (Orang) \\
& Keluhan & & \\
\hline
\end{tabular}


Klasifikasi Keluhan Tamu Mengenai Pelayanan Front Office di The Westin Resort Nusa Dua Bali Berdasarkan ......

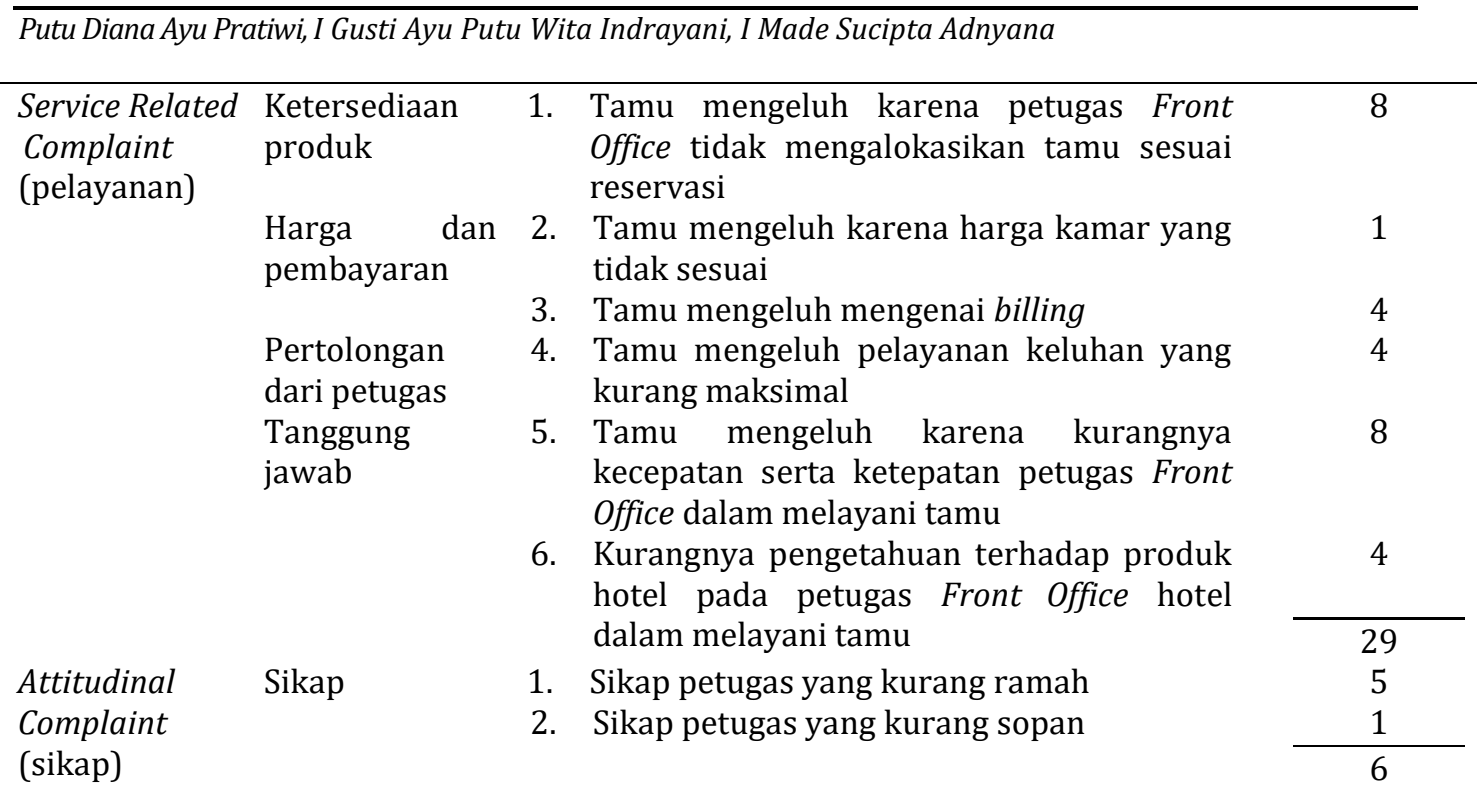

Tabel 2 menunjukkan bahwa keluhan tamu pada aspek pelayanan yang banyak terjadi adalah keluhan mengenai dimensi ketersediaan produk. Keluhan tersebut mengenai petugas Front Office yang tidak mengalokasikan tamu sesuai reservasi dengan jumlah delapan orang dari 29 orang yang mengeluh. Selain itu, keluhan yang banyak terjadi adalah keluhan mengenai dimensi tanggung jawab. Keluhan mengenai kurangnya kecepatan serta ketepatan petugas Front Office dalam melayani tamu dengan jumlah delapan orang dari 29 orang yang mengeluh. Sedangkan keluhan tamu pada aspek sikap petugas dalam dimensi sikap yang banyak terjadi adalah keluhan mengenai sikap petugas yang kurang ramah dengan jumlah lima orang dari enam orang yang mengeluh.

Dalam menjalankan operasionalnya, petugas Front Office harus bekerja sesuai dengan Standard Operating Procedures yang telah ditetapkan. Prosedur pelayanan terhadap tamu yang diberikan petugas Front Office diklasifikasikan berdasarkan siklus kegiatan tamu. Studi dokumentasi dilakukan pada tanggal 29 Maret 2021 dengan mengumpulkan data SOP yang diberikan oleh Front Office Manager. Data SOP dikumpulkan dan diproses kembali agar menyesuaikan dengan siklus kegiatan tamu. Hal ini bertujuan untuk memudahkan mengidentifikasi prosedur pelayanan yang diduga menjadi penyebab keluhan tamu. Prosedur pelayanan Front Office di The Westin Resort Nusa Dua Bali dapat dilihat pada Tabel 3 dibawah ini.

Tabel 3: Prosedur Pelayanan Front Office di

The Westin Resort Nusa Dua Bali Berdasarkan Siklus Tamu

[Sumber: Front Office Department The Westin Resort Nusa Dua Bali (data diolah)]

\begin{tabular}{llll}
\hline No & \multicolumn{1}{c}{ Siklus Tamu } & & \multicolumn{1}{c}{ Prosedur Pelayanan Front Office } \\
\hline 1 & Pre-arrival & 1. & Mengecek profil tamu secara menyeluruh \\
& & 2. & Mengkoordinasikan permintaan tamu yang bersifat khusus \\
& Arrival & 1. & Menyambut kedatangan tamu \\
& & 2. & Menangani check-in \\
& Stay & 1. & Menangani permintaan tamu \\
& & 2. & Menangani keluhan tamu \\
& 3. & Menjaga akurasi terhadap folio tamu \\
& Departure & 1. & Menyiapkan keperluan sebelum tamu check-out \\
& & 2. & Menangani proses check-out \\
& 3. & Collecting guest feedback \\
\hline
\end{tabular}

Jurnal Bisnis Hospitaliti Vol. 10. No. 2 
Putu Diana Ayu Pratiwi, I Gusti Ayu Putu Wita Indrayani, I Made Sucipta Adnyana

Menurut Sambodo (2020:21) semua proses kegiatan tamu mengacu pada tahapan yaitu mulai dari pre-arrival, arrival, stay, sampai dengan departure. Prosedur pelayanan Front Office yang dijabarkan dalam Tabel 3.2 menunjukkan bahwa prosedur pelayanan petugas Front Office dalam melayani tamu mengacu pada siklus tamu. Pada saat sebelum kedatangan tamu (pre-arrival), petugas Front Office harus mengecek profil tamu dan mengkoordinasikan segala bentuk permintaan tamu yang bersifat khusus. Pada saat kedatangan tamu (arrival) petugas Front Office harus menyambut kedatangan tamu lalu menangani tamu check-in. Pada saat tamu menginap (stay) petugas Front Office harus menangani permintaan tamu, menangani keluhan tamu, serta menjaga akurasi terhadap folio tamu. Pada saat keberangkatan tamu (departure) petugas Front Office harus menyiapkan keperluan sebelum tamu check-out, menangani proses check-out, serta Collecting guest feedback.

\subsection{PEMBAHASAN}

Klasifikasi keluhan tamu terhadap pelayanan Front Office di The Westin Resort Nusa Dua Bali, aspek keluhannya dibagi menjadi dua yaitu, aspek pelayanan (service related complaint) dan keluhan mengenai sikap petugas (attitudinal complaint). Service related complaint adalah keluhan yang terjadi akibat pelayanan yang diberikan petugas Front Office. Pada aspek pelayanan (service related complaint) dengan dimensi penyebab keluhan tamu yakni ketersediaan produk, harga dan pembayaran, pertolongan dari petugas, dan tanggung jawab berjumlah 29 orang yang mengeluh. Adapun keluhannya secara spesifik diuraikan berikut ini.

Tamu mengeluh karena petugas Front Office tidak mengalokasikan tamu sesuai dengan reservasinya. Keluhan ini berjumlah delapan orang dari 29 orang yang mengeluh. Spesifik keluhannya seperti: kamar yang dipesan tamu adalah suite room namun petugas Front Office mengalokasikannya pada standard room, upgrade room yang sudah dijanjikan dibatalkan, kamar yang dipesan tidak tersedia saat check-in, petugas Front Office memberikan kamar dengan kulkas yang rusak kepada tamu saat check-in. Keluhan ini disebabkan karena overbooked atau tingkat pemesanan kamar yang diterima terlalu tinggi melebihi jumlah kamar yang tersedia, sehingga petugas Front Office harus mengalokasikan tamu berdasarkan kamar yang tersedia pada saat itu. Keluhan tersebut berdampak pada hilangnya kepercayaan tamu terhadap produk yang dijual hotel. Upaya yang seharusnya dilakukan petugas Front Office dalam menangani keluhan tersebut adalah memberikan upgrade room dengan harga yang sesuai kamar yang telah dipesan tamu.

Tamu mengeluh karena harga kamar yang tidak sesuai. Keluhan ini berjumlah satu orang dari 29 orang yang mengeluh. Spesifik keluhannya seperti: saat check-in harga kamar yang dibayarkan berbeda saat dipesan. Keluhan ini disebabkan karena kurangnya komunikasi antara petugas reservasi dan petugas Front Office dalam mengubah harga kamar. Harga kamar pada Front Office mengikuti Flowsystem pada Website, sedangkan petugas reservasi terkadang memberikan harga kamar manual yang ditulis dalam confirmation letter. Keluhan tersebut berdampak pada kesalahan informasi yang diberikan petugas hotel kepada tamu. Upaya yang seharusnya dilakukan petugas Front Office dalam menangani keluhan ini adalah dengan cara menyesuaikan harga kamar yang pada confirmation letter dengan sistem.

Tamu mengeluh karena pelayanan keluhan yang kurang maksimal. Keluhan ini berjumlah empat orang dari 29 orang yang mengeluh. Spesifik keluhannya seperti: petugas Front Office tidak berempati terhadap masalah yang dikeluhkan tamu, petugas Front Office tidak dapat membantu untuk menangani masalah pembayaran yang dikeluhkan tamu, petugas Front Office kurang fleksibel dalam menangani keluhan tamu, petugas tidak bisa membantu untuk menangani masalah pembatalan rencana menginapnya, sehingga tamu tetap dikenakan biaya penuh untuk kamar yang telah dipesan tamu, petugas Front Office tidak mengindahkan permintaan tamu yang ingin 
pindah kamar. Keluhan ini disebabkan karena kurangnya rasa tanggung jawab petugas Front Office dalam melakukan tugasnya untuk menangani keluhan tamu. Keluhan tersebut berdampak pada kinerja petugas Front Office yang dilihat kurang kompeten dalam menangani keluhan tamu. Upaya yang seharusnya dilakukan petugas Front Office dalam menangani keluhan ini adalah dengan memposting keluhan tamu pada GXP, sehingga Duty Manager dan atau Departement Head yang bersangkutan dengan masalah yang dikeluhkan tamu akan menangani keluhan tersebut.

Tamu mengeluh mengenai billing. Keluhan ini berjumlah empat orang dari 29 orang yang mengeluh. Spesifik keluhannya seperti: tamu dikenakan biaya pada pembayaran yang seharusnya di holding dahulu sebagai deposit, pengembalian deposit yang tidak pernah sampai ke pihak tamu, keluhan mengenai pre-payment saat check-in. Keluhan pembayaran ini disebabkan karena petugas Front Office yang kurang fokus saat menangani pembayaran tamu. Keluhan tersebut berdampak pada kompleksitas tindak lanjut yang harus dilakukan pihak Front Office dalam menangani keluhannya. Upaya yang seharusnya dilakukan petugas Front Office dalam menangani keluhan ini adalah dengan cara melakukan void pada EDC machine, sedangkan untuk masalah refund deposit, petugas Front Office bisa mengonfirmasi langsung pada pihak bank dan langsung memberikan bukti pengajuan refund yang telah diproses bank kepada pihak tamu.

Tamu mengeluh karena kurangnya kecepatan serta ketepatan petugas Front Office dalam melayani tamu. Keluhan ini berjumlah delapan orang dari 29 orang yang mengeluh. Spesifik keluhannya seperti: durasi proses check-in dan check-out yang terlalu lama, tamu terlalu lama mengantri untuk proses check-in, kue ulang tahun yang dijanjikan petugas Front Office tidak pernah diantar ke kamar tamu. Keluhan mengenai kecepatan check-in disebabkan karena kamar yang belum siap. Keluhan tersebut berdampak pada hilangnya kepercayaan tamu terhadap janji yang diberikan petugas. Upaya yang seharusnya dilakukan petugas Front Office dalam menangani keluhan ini adalah dengan cara mengkomunikasikan segala bentuk kesiapan kamar dengan Housekeeping Department, sedangkan keluhan mengenai ketepatan pelayanan petugas Front Office dalam melayani tamu disebabkan karena kurangnya pengetahuan pada petugas Front Office dalam melayani tamu. Keluhan tersebut berdampak pada kinerja petugas Front Office yang dilihat kurang kompeten dalam melayani tamu. Upaya yang seharusnya dilakukan petugas Front Office dalam menangani keluhan ini adalah dengan mengikuti pelatihan untuk mendapatkan informasi yang bersangkutan dengan pelayanan terhadap tamu.

Kurangnya pengetahuan terhadap produk hotel pada petugas Front Office hotel dalam melayani tamu. keluhan ini berjumlah empat orang dari 29 orang yang mengeluh. Spesifik keluhannya seperti: informasi transportasi dalam paket yang tidak jelas, petugas Front Office tidak memberikan peta hotel dan kids club information timetable. Keluhan ini disebabkan karena petugas Front Office lupa memberikan informasi yang berkaitan dengan fasilitas hotel kepada tamu dan kurangnya sosialisasi mengenai produk atau pelayanan untuk tamu, sehingga petugas Front Office kurang memahami dengan teliti produk atau pelayanan hotel yang diberikan kepada tamu. Keluhan tersebut berdampak pada kinerja petugas Front Office yang dilihat kurang kompeten dalam melayani tamu. Upaya yang seharusnya dilakukan petugas Front Office dalam menangani keluhan ini adalah dengan cara mengikuti pelatihan untuk mendapatkan informasi yang bersangkutan dengan pelayanan terhadap tamu.

Selanjutnya, attitudinal complaint adalah keluhan yang disebabkan oleh sikap negatif yang ditunjukkan petugas Front Office dalam melayani tamu. Pada aspek sikap petugas (attitudinal complaint) dengan dimensi penyebab keluhan tamu yakni sikap yang berjumlah enam orang yang mengeluh, Adapun keluhannya secara spesifik diuraikan berikut ini.

Sikap petugas yang kurang ramah. Keluhan ini berjumlah lima orang dari enam orang yang mengeluh. Spesifik keluhannya seperti: petugas Front Office yang kurang 
ramah dan kurang menyapa saat bertemu tamu. Keluhan tersebut berdampak pada persepsi negatif tamu terhadap citra hotel. Upaya yang bisa dilakukan adalah dengan service basic training yang perlu diberikan pada petugas Front Office untuk meminimalisir keluhan yang berulang.

Sikap petugas yang kurang sopan. Keluhan ini berjumlah satu orang dari enam orang yang mengeluh. Spesifik keluhannya seperti: saat check-out, tamu dituduh mencuri informasi kartu kredit oleh petugas Front Office. Hal ini disebabkan karena kebijakan The Westin Resort Nusa Dua Bali yang sangat ketat dalam menerima informasi tamu, sehingga tamu merasa tersinggung saat diinformasikan mengenai kebijakan tersebut. Keluhan tersebut berdampak pada persepsi negatif tamu terhadap kebijakan hotel. Upaya yang seharusnya dilakukan seorang petugas Front Office dalam menangani keluhan ini adalah dengan berbicara yang sopan dan menjelaskan dengan baik mengenai kebijakan tersebut.

Prosedur pelayanan Front Office dalam melayani tamu mengacu pada siklus kegiatan tamu. Wawancara mengenai Standard Operating Procedures yang diterapkan petugas Front Office dalam melayani tamu ini dilakukan peneliti dengan Front Office Manager pada 30 Mei 2021 yang bertempat di ruangan Front Office Department The Westin Resort Nusa Dua Bali. Berdasarkan wawancara dengan Front Office Manager, diketahui bahwa persentase SOP yang diterapkan petugas Front Office harus mencapai $100 \%$. Namun, beberapa kriteria pelaksanaan kerjanya ada yang belum mencapai $100 \%$ dikarenakan beberapa hal, seperti kurangnya ketelitian petugas Front Office dalam melayani tamu yang mengakibatkan keluhan pada aspek attitudinal complaint dan service related complaint. Berdasarkan hasil wawancara, persentase SOP yang diterapkan petugas Front Office dapat diuraikan sebagai berikut:

Pada siklus pre-arrival, hal-hal yang harus dilakukan petugas Front Office yaitu mengecek profil tamu secara menyeluruh dan mengkoordinasikan permintaan tamu yang bersifat khusus. Pada siklus ini, pelayanan yang diterapkan sudah mencapai 100\% sesuai dengan SOP yang telah ditetapkan. Hal ini dikarenakan sebelum memulai shift-nya, petugas Front Office selalu mengecek profil tamu pada sistem LightSpeed untuk mengetahui informasi mengenai tamu yang akan tiba. Selain itu, sebelum memulai shiftnya, petugas Front Office juga mengikuti briefing untuk mengetahui informasi-informasi yang berkaitan dengan tamu. Petugas Front Office juga selalu mengkomunikasikan segala bentuk kebutuhan tamu yang bersifat khusus (special request) dengan departemen yang bersangkutan. Petugas Front Office juga harus melakukan cross-check untuk memastikan bahwa setiap kebutuhan tamu sudah diakomodir dengan baik dan sesuai.

Pada siklus arrival, hal-hal yang harus dilakukan petugas Front Office yaitu menyambut kedatangan tamu dan menangani proses check-in. Pada siklus ini, pelayanan yang diterapkan hanya mencapai $98 \%$ dari SOP yang telah ditetapkan. Sedangkan kriteria yang belum mencapai $100 \%$ dapat diuraikan sebagai berikut:

1) Menyambut kedatangan tamu

Pada kriteria pelaksanaan kerjanya, petugas Front Office harus memberi salam dengan ramah sesuai dengan standar hotel yaitu panganjali umat. Pada pelayanan ini, kriteria pelaksanaan kerjanya hanya mencapai $97 \%$ dari SOP yang telah ditetapkan. Hal ini karena salah satu kriteria dalam menyambut kedatangan tamu yaitu memberi salam dengan ramah sesuai standar hotel hanya mencapai 95\%. Hal ini disebabkan karena petugas Front Office lupa untuk memberikan salam saat tamu tiba. Selain itu hal ini dikarenakan petugas Front Office terlalu terburu-buru saat melayani tamu. Sehingga ketidaksesuaian SOP yang diterapkan menyebabkan keluhan tamu pada aspek attitudinal complaint yaitu sikap petugas yang kurang ramah. Petugas Front Office seharusnya memberi perhatian penuh saat melayani tamu, sehingga ketidaksesuaian SOP bisa lebih diminimalisir.

2) Menangani proses check-in 
Pada kriteria pelaksanaan kerjanya, petugas Front Office harus mengalokasikan tamu sesuai dengan reservasi, mengonfirmasi pemesanan kamar, mengonfirmasi harga kamar dan metode pembayaran, dan menjelaskan informasi mengenai program loyalty member. Pada pelayanan ini, kriteria pelaksanaan kerjanya hanya mencapai 98,75\% dari SOP yang ditetapkan. Hal ini karena salah satu kriteria dalam menangani proses check-in yaitu mengalokasikan tamu sesuai reservasi hanya mencapai 95\%. Hal ini disebabkan karena hotel mengalami overbooked, sehingga petugas Front Office harus mengalokasikan tamu pada kamar yang tersedia pada saat itu. Ketidaksesuaian SOP yang diterapkan menyebabkan keluhan tamu pada aspek service related complaint yaitu keluhan mengenai petugas Front Office yang tidak mengalokasikan tamu sesuai dengan reservasi. Petugas Front Office seharusnya meningkatkan status kamar atau memberi benefit lainnya sebagai solusi alternatif untuk menghindari keluhan pada tamu.

Pada siklus stay, hal-hal yang harus dilakukan petugas Front Office yaitu menangani permintaan tamu, menangani keluhan tamu, dan menjaga akurasi pada folio tamu. Pada siklus ini, pelayanan yang diterapkan hanya mencapai $99 \%$ dari SOP yang telah ditetapkan. Kriteria yang belum mencapai $100 \%$ adalah menangani permintaan tamu. Pada kriteria pelaksanaan kerjanya, petugas Front Office harus menangani permintaan tamu pindah kamar, issuing voucher, dan menangani permintaan tambahan kunci kamar. Pada pelayanan ini, kriteria pelaksanaan kerjanya hanya mencapai $98,3 \%$ dari SOP yang ditetapkan. Hal ini karena salah satu kriteria dalam menangani permintaan tamu yaitu menangani permintaan tamu pindah kamar hanya mencapai 95\%. Hal ini dikarenakan saat tamu ingin pindah kamar, petugas Front Office harus mengecek ketersediaan kamar pada saat itu. Jika pada saat itu hotel mengalami overbooked, kemungkinan besar petugas Front Office tidak bisa mengalokasikan tamu sesuai dengan permintaannya. Hal ini juga diidentifikasi sebagai penyebab service related complaint pada dimensi ketersediaan produk. Petugas Front Office seharusnya bisa mengkomunikasikan keterbatasan tersebut dan menawarkan solusi alternatif seperti pindah kamar pada hari berikutnya.

Pada siklus departure, hal-hal yang harus dilakukan petugas Front Office yaitu mempersiapkan kelengkapan sebelum tamu check-out, menangani proses check-out, dan mengumpulkan guest feedback. Pada siklus ini, pelayanan yang diterapkan hanya mencapai 99\% dari SOP yang telah ditetapkan. Kriteria yang belum mencapai 100\% adalah mempersiapkan kelengkapan tamu sebelum tamu check-out. Pada kriteria pelaksanaan kerjanya, petugas Front Office harus memeriksa daftar tamu yang akan check-out dan mempersiapkan registration card beserta bukti tagihan tamu yang akan check-out. Pada pelayanan ini, kriteria pelaksanaan kerjanya hanya mencapai $97,5 \%$ dari SOP yang ditetapkan. Hal ini dikarenakan salah satu kriteria dalam mempersiapkan kelengkapan tamu sebelum tamu check-out yaitu mempersiapkan registration card dan bukti tagihan tamu yang akan check-out hanya mencapai 95\% dari SOP yang telah ditetapkan. Hal ini dikarenakan saat tingkat hunian kamar tinggi, petugas Front Office cukup kewalahan untuk menangani proses check-in dan check-out dalam waktu yang bersamaan. Hal tersebut menyebabkan petugas Front Office terkadang tidak mengecek dan menyiapkan bukti tagihan tamu saat sebelum tamu check-out. Hal ini juga diidentifikasi sebagai penyebab service related complaint yaitu kurangnya kecepatan dan ketepatan petugas Front Office dalam melayani tamu. Petugas Front Office pada night shift seharusnya mengecek segala kelengkapan tamu yang akan check-out pada keesokan harinya untuk mempercepat proses check-out.

\section{KESIMPULAN}

Berdasarkan hasil analisis data yang telah diuraikan pada pembahasan, maka kesimpulan yang didapa yaitu Klasifikasi keluhan tamu mengenai pelayanan Front Office di The Westin Resort Nusa Dua Bali diklasifikasikan kedalam dua aspek keluhan tamu 
yaitu aspek service related complaint atau keluhan mengenai pelayanan dan aspek attitudinal complaint atau keluhan mengenai sikap petugas. Penyebab dari keluhan tamu pada aspek service related complaint adalah petugas Front Office tidak menerapkan prosedur sesuai dengan standar yang telah ditetapkan. Sedangkan, penyebab dari aspek attitudinal complaint adalah sikap petugas Front Office yang kurang ramah dalam melayani tamu. Keluhan tersebut berdampak pada persepsi tamu yang cenderung negatif terhadap operasional Front Office. Dari hasil analisis juga dapat disimpulkan bahwa prosedur pelayanan Front Office pada siklus tamu saat arrival, stay, dan departure belum mencapai $100 \%$ kesesuaian dengan SOP yang telah ditetapkan dikarenakan petugas Front Office kurang mendapatkan pelatihan dan sosialisasi mengenai SOP dalam melayani tamu, serta petugas Front Office kurang memahami pentingnya penerapan SOP dalam melayani tamu, sehingga hal tersebut menimbulkan keluhan tamu pada aspek attitudinal complaint dan service related complaint.

Berdasarkan kesimpulan di atas, saran yang dapat diberikan untuk meningkatkan pelayanan pada petugas Front Office dalam melayani tamu agar keluhan yang berulang bisa diminimalisir yaitu Petugas Front Office diharapkan bisa meningkatkan pelayanannya dalam melayani tamu dengan cara mengikuti refreshment training yaitu pelatihan untuk penyegaran (refresh). Pelatihan ini diharapkan mampu untuk membuat petugas Front Office lebih berpikir dinamis dalam pola pikir maupun penanganan terhadap pelayanan yang diberikan untuk tamu. Selain itu, petugas Front Office juga diharapkan untuk bisa bekerja lebih fokus dan lebih teliti dalam melayani tamu dengan cara selalu memeriksa dan memastikan kembali segala bentuk pelayanan yang diberikan kepada tamu. Hal tersebut menjadi salah satu cara agar keinginan serta kebutuhan tamu dapat terpenuhi dengan benar dan tepat, sehingga hal-hal yang menimbulkan keluhan pada tamu pada aspek attitudinal complaint dan service related complaint tidak terulang dan bisa diminimalisir. Front Office Manager diharapkan mampu untuk melakukan monitoring terhadap pelatihan mengenai kinerja petugas Front Office yang belum sesuai SOP dengan cara selalu mengevaluasi hasil dari segala pelatihan yang diberikan kepada petugas Front Office, sehingga berdasarkan hasil evaluasi, Front Office Manager bisa mengetahui prosedur mana yang harus ditingkatkan penerapannya oleh petugas Front Office dalam melayani tamu mulai dari pre-arrival, arrival, stay, sampai dengan departure.

\section{PERNYATAAN PENGHARGAAN}

Penulis mengucapkan terima kasih yang sebesar-besarnya kepada bapak Wayan Geria Juliartha selaku Front Office Manager serta seluruh karyawan dan pimpinan The Westin Resort Nusa Dua Bali yang telah bersedia menjadi narasumber sehingga penulis dapat memperoleh informasi yang berguna dalam penyusunan artikel ilmiah ini.

\section{DAFTAR PUSTAKA}

Ali, F. (2015). Service quality as a determinant of customer satisfaction and resulting behavioural intentions: a SEM approach towards Malaysian resort hotels. Tourism, 63 (1), 37-51.

Bell \& Luddington. (2014). Coping with Customer Complaint. Journal of Service Research, 8 , 221. Sage Published.

Blumenthal, M. (2016). GatherUp: Survey: 8 Things That Really Cause Consumers to Complaint. Diakses dari https://gatherup.com/blog/what-makes-consumerscomplain/

Bonelli, S. (2016). SmxAdvanced: 70\% of Consumers Will Leave a Review for a Bussiness When Asked. Dikases dari https://searchengineland.com/70-consumers-will-leavereview-business-asked-262802 
Putu Diana Ayu Pratiwi, I Gusti Ayu Putu Wita Indrayani, I Made Sucipta Adnyana

Gonius, N. (2013). Study Deskriptif Tentang Customer Complaint di Restoran Wok Noodles di Galaxy Mall Surabaya. Jurnal Ilmiah Mahasiswa Universitas Surabaya, 2, 8-17.

Khoo-Lattimore, C. \& Ekiz, E.H. (2014). Power in praise: exploring online compliments on luxury hotels in Malaysia. Tour. Hosp. Res, 14 (3), 152-159.

Kusumastuti \& Yonasari. 2018. Gambaran Penanganan Keluhan Pelanggan di Unit Customers Service Rumah Sakit Umum Daerah Tugurejo Semarang. Jurnal Kesehatan Masyarakat, 6(5).

Mohsin, A. \& Lockyer, T. (2010). Customer perceptions of service quality in luxury hotels in New Delhi, India: an exploratory study. International Journal of Contemporary Hospitality Management, 22 (2), 160-173.

Mohsin, A., Hussain, I. \& Khan, M.R. (2011). Exploring service quality in luxury hotels: case of Lahore, Pakistan. Journal of American Academic Business, 16 (2), 296-303.

Mukhtar. (2013). Metode Praktis Penelitian Deskriptif Kualitatif. Jakarta: Referensi

Mullachery, V. (2014). SiteMinder: Hotel reviews: How to Manage Online Guest Review at Your Property. Diakses dari https://www.siteminder.com/r/hotel-reviewsmanage-online-property/.

Murphy, R. l. (2020). BrightLocal: The 40 Online Reviews Statistic You Need in 2020. Diakses dari https://www.brightlocal.com/resources/online-reviews-statistics .

Padma, P. \& Ahn, J. (2020). Guest satisfaction \& dissatisfaction in luxury hotels: An application of big data. International Journal of Hospitality Management, 84.

Parasuraman, A., Zeithaml, V.A. \& Berry, L.L. (1985). A conceptual model of service quality and its implications for future research. Journal of Marketing, 49 (4), 41-50.

Parasuraman, A., Zeithaml, V.A. \& Berry, L.L. (1988). Servqual: a multiple-item scale for measuring consumer perc. Journal of Retail, 64 (1), 12-40.

Rhee, H.T. \& Yang, S.B. (2015). Does hotel attribute importance differ by hotel? Focusing on hotel star-classifications and customers' overall ratings. Journal of Computer and Human Behaviour, 50, 576-587.

Sambodo, A. (2020). Kantor Depan Hotel. Makassar: Penerbit Nas Media Pustaka.

Saputra, I. (2021). Bentuk Digitalisasi Desa Wisata Di Masa Normal Baru (Studi Kasus Desa Sayan Ubud Bali). Jurnal Kepariwisataan, 20 (1).

Saragih, L.S. (2019). Dampak Online Travel Agent (OTA) Dalam Meningkatkan Pengunjung di Pardede Internasional Hotel Medan. Journal for Business and Entrepreneur, 3(1).

Sugiarto, E. (2004). Operasional Kantor Depan Hotel. Jakarta: Pt Gramedia.

Widyana \& Nurjanah. (2018). Analisis Penanganan Keluhan Pos Express Pada Kantor Pos Cimahi. Jurnal Bisnis Pemasaran, 8(1). 